\title{
Reproductive biology of Steindachnerina insculpta (Fernandez-Yépez) (Teleostei, Curimatidae) in Furnas reservoir, Minas Gerais, Brazil
}

\author{
Vinicius M. A. Ribeiro; Gilmar B. Santos \& Nilo Bazzoli
}

Programa de Pós-graduação em Zoologia de Vertebrados, Universidade Católica de M inas Gerais. Rua Dom José Gaspar 500, 30535-610 Belo Horizonte, Minas Gerais, Brasil.

\begin{abstract}
The 'saguiru' Steindachnerina insculpta, a small teleost detritivorous fish species in Furnas reservoir, upper rio Paraná basin, Minas Gerais, Brazil, has a prolonged period of reproductive activity that extends from September to March, with fractionated spawning. During gonadal maturation, the females showed a low hepatosomatic index, suggesting that hepatic substances are possibly transferred from liver to ovaries. During the reproductive period, this fish had lower stomach repletion and coelomic fat indexes, indicating that the species eat less and consume more fat reserves. The weight of the ovaries influenced positively the condition factor (K1), since the lowest K2 values (without the gonads weight), were obtained during maturation, confirming the influence of the weight of the ovaries upon the physiological condition of the females.
\end{abstract}

KEY WORDS. Freshwater teleost fish; reproduction; spawning,.

\begin{abstract}
RESUMO. Biologia reprodutiva de Steindachnerina insculpta (Fernandez-Yépez) (Teleostei, Curimatidae) no reservatório de Furnas, Minas Gerais, Brasil. O ‘saguiru’ Steindachnerina insculpta, peixe teleósteo detritívoro que ocorre no reservatório de Furnas, bacia do alto Paraná, Minas Gerais, apresenta período reprodutivo prolongado que se estende de setembro a março, com desova parcelada. Durante a maturação gonadal, fêmeas apresentaram baixos valores do índice hepatossomático, sugerindo que possivelmente, substâncias hepáticas são transferidas do fígado para os ovários. Durante o período reprodutivo, os peixes desta espécie apresentam índices de repleção estomacal e de gordura celômica baixos, indicando diminuição da atividade alimentar e consumo de reservas. $O$ peso dos ovários influencia positivamente o fator de condição (K1), uma vez que os mais baixos valores de K2 (sem o peso das gônadas) foram obtidos durante a maturação, confirmando a influência do peso dos ovários na condição fisiológica das fêmeas.
\end{abstract}

PALAVRAS-CHAVE. Desova; reprodução; teleósteo de água doce.

Furnas reservoir was built in 1962 by damming the Grande River. It has $1522 \mathrm{~km}^{2}$ of maximum flooding area, a depth of $15.4 \mathrm{~m}$ and $20.86 \times 10^{9} \mathrm{~m}^{3}$ of water volume. The reservoir has a dendritic shape and a fish fauna in which small and mediumsized species are dominant (SANTOS \& FormagIO 2000).

The 'saguiru' Steindachnerina insculpta (Fernandez-Yépez, 1948), a small detritivorous fish species, has its geographic distribution in the upper Paraná river basin, South America and it is important to the food chain maintenance (Rels et al. 2003). The species has an illiophagus feeding habit reaching a maximum total length of $15 \mathrm{~cm}$ for males and $21 \mathrm{~cm}$ for females in the Mogi Guassu river (Godoy 1975). There are few studies related to this species, included those concerning gillnet selectivity evaluations in Ibitinga reservoir, Tietê river (CAmpos et al. 1991), and the determination of the spawning areas and period in Itaipu reservoir, upper Paraná river basin (BeneditoCecílio \& Agostinho 1997).
The reproductive cycle is an important parameter in understanding the reproduction of native fish species and to the establishment of conservation programs (VAZzOLER 1996). The oocytes released by the females in the reproductive period may be total or fractioned. In tropical environments, total spawning usually occurs in large fish species that migrate over long distances and reproduce, usually in markedly seasonal lotic environments. Fractioned spawning, on the other hand, is frequent in fish living in stable, lentic environments being associated with reduced body size and relatively small ovaries of these species (NIKOLSKI 1963). Fractioned spawning is characterized by asynchronous oocyte development, long period of reproduction and high frequency of females with partially spawned ovaries (RINCHARD \& KESTEMONT 1996). It constitutes a reproductive strategy designed to reduce the egg and larvae predation, the risk of spawning in unfavorable hydrographic and climatic conditions, and the competition for spawning sites (Mcevor \& M cevor 1992). 
The fish energetic needs, which increase during gonadal maturation to meet the different reproductive strategies, are reduced in the period that precedes spawning and spermiation. Feeding is interrupted and endogenous nutrients are converted into energy for reproduction, with a consequent reduction in body weight and energetic reserves (MADDOCK \& BURTON 1999). In tropical environments feeding plays a fundamental role in determining reproductive rhythm (VAZZOLER \& Menezes 1992). Variations in fish coelomic fat level (CFI) may be related to their reproductive cycle as well as the river or reservoir hydrologic cycle (LAmAs \& Godinho 1996). During the reproductive cycle, the condition factor $(K)$ may vary according to the feeding conditions and gonadal development and may be used, for some species, as an indicator of spawning period (BarbierI \& VeranI 1987).

The present work focuses on the reproductive biology of S. insculpta in Furnas reservoir by determining the reproductive cycle stages, reproductive period length, type of spawning and the biological indexes related to the species reproduction.

\section{MATERIALS AND METHODS}

Two hundred and fifty males and five hundred and eleven femal es were captured in the Furnas reservoir, Minas Gerais State, Brazil (20\%40'S, 4619'W) from September 1992 to August 1994, using gill nets. All captured specimens were fixed in $10 \%$ formalin solution. After dissection, sex identification, and macroscopic determination of the stages of the reproductive cycle, the following data were recorded for each specimen: standard length (SL), body (BW), gonads (GW), liver (LW), stomach (SW), and coelomic fat (CFW) weights. The biometric data obtained were used for calculating the gonadosomatic (GW/BW x 100), hepatosomatic (LW/BW $\times 100)$, stomach repletion (SW/BW $\times 100)$ and coelomic fat (CFW/BW $\times 100)$ indexes, as well as the condition factors $\left(\mathrm{K} 1=\mathrm{BW} / \mathrm{SL}^{3} ; \mathrm{K} 2=\mathrm{BW}-\mathrm{GW} / \mathrm{SL}^{3}\right)$. The stages of the reproductive cycle were established using the macroscopic characteristics of the gonads, whereas the spawning type was determined by analysis of the frequency distribution of the referred stages (BAzzol 2003). Data were analyzed quarterly according to the season of the year. An ANOVA test was performed for testing variations in the mean values of the indexes calculated for each stage of reproductive cycleand by sex. When needed, a Duncan's test was applied for determining statistically significant differences ( $p$ <0.05) (SAmpalo 1998).

\section{RESULTS}

The testes and ovaries of S. insculpta are el ongated, paired organs, located latero-dorsally in the coelomic cavity and ventro-laterally to the gaseous bladder. They were attached to the coelomic wall and to the gaseous bladder by the mesorchium and mesovarium, respectively. Both testes and ovaries are joined in their caudal ends, forming the common duct that opens in the urogenital papilla. Variations in thickness, volume and color of the gonads were observed in the distinct stages of the reproductive cycle. Based on the variations in color, vascularization, volume, and turgidity, the following stages of the reproductive cycle of S. insculpta were determined: $1=$ rest, $2=$ initial ripening, 3 =advanced ripening/mature, $4 \mathrm{~A}=$ partially spent for males and partially spawned for females, and $4 B=$ totally spent for males and totally spawned for females (Tab. I). Over most of the study period, there was low occurrence of males and females in the rest stage. Males and females in the initial ripening and mature stages occurred practically in all trimesters of the two years studied, with a higher frequency of mature specimens in December-January-February. Spent/ spawned males and females also occurred in almost all quarters sampled, but were found more frequently in March-AprilMay and June-July-August (Fig. 1).

The high frequency of partially spawned females in the two studied cycles, with occurrence of the extended reproductive period from September to March (Fig. 1), accompanied by quarterly variations in the gonadosomatic index, indicate that $\mathrm{S}$. insculpta has a fractionated type spawning. The mean gonadosomatic index for males and females increased significantly ( $p<0.05$ ) from stage 1 to stage 3 and decreased thereafter $(p<0.05)$ (Tabs II, III). The mean hepatosomatic index for females increased from stage 1 to stage 2 and decreased abruptly in stage 3 ( $p<0.05)$. The mean stomach repletion index was significantly lower in stage 3 , for males and females $(p<0.05)$. The mean coelomic fat index did not show statistically significant differences. The mean of the condition factors (KI and K2) values for males did not show statistically significant differences during the reproductive cycle. For females, the K1 values were significantly higher in stage 3 (Tabs II, III).

\section{DISCUSSION}

Ovaries and testes of S. insculpta are paired, elongated and fusiforms organs located in the coelomic cavity, ventrally to the kidneys, dorsally to the digestive tube and latero-ventrally attached to the gas bladder, similar to those found in other Brazilian Curimatidae (Alves \& Godinho 1992, Alvarenga et al. 2006).

In all quarters studied, males and females in reproductive activity and having fractionated-type spawning were recorded. An extended reproductive period and a fractionated spawning type appear to be characteristic for the most of Curimatidae (Romagosa et al. 1984, Alves \& Godinho 1992, HaRTZ \& BARBIERI 1994). However, Curimatella lepidura (Eigenmann \& Eigenmann, 1889) has a total spawning type (AlvarengA et al. 2006). The prolonged reproductive period, common in several Brazilian teleosts, occurs as a response to the conditions in tropical waters (Lowe-M cConnell 1987).

In this work, the variations in the GSI of males were more discreet, if compared to those of the females, and can be attributed to the differences between testes and ovaries (in terms of volume, mass and energetic demand required for the production of gametes). These results are similar to the findings of SLOTTE

Revista Brasileira de Zoologia 24 (1): 71-76, março 2007 

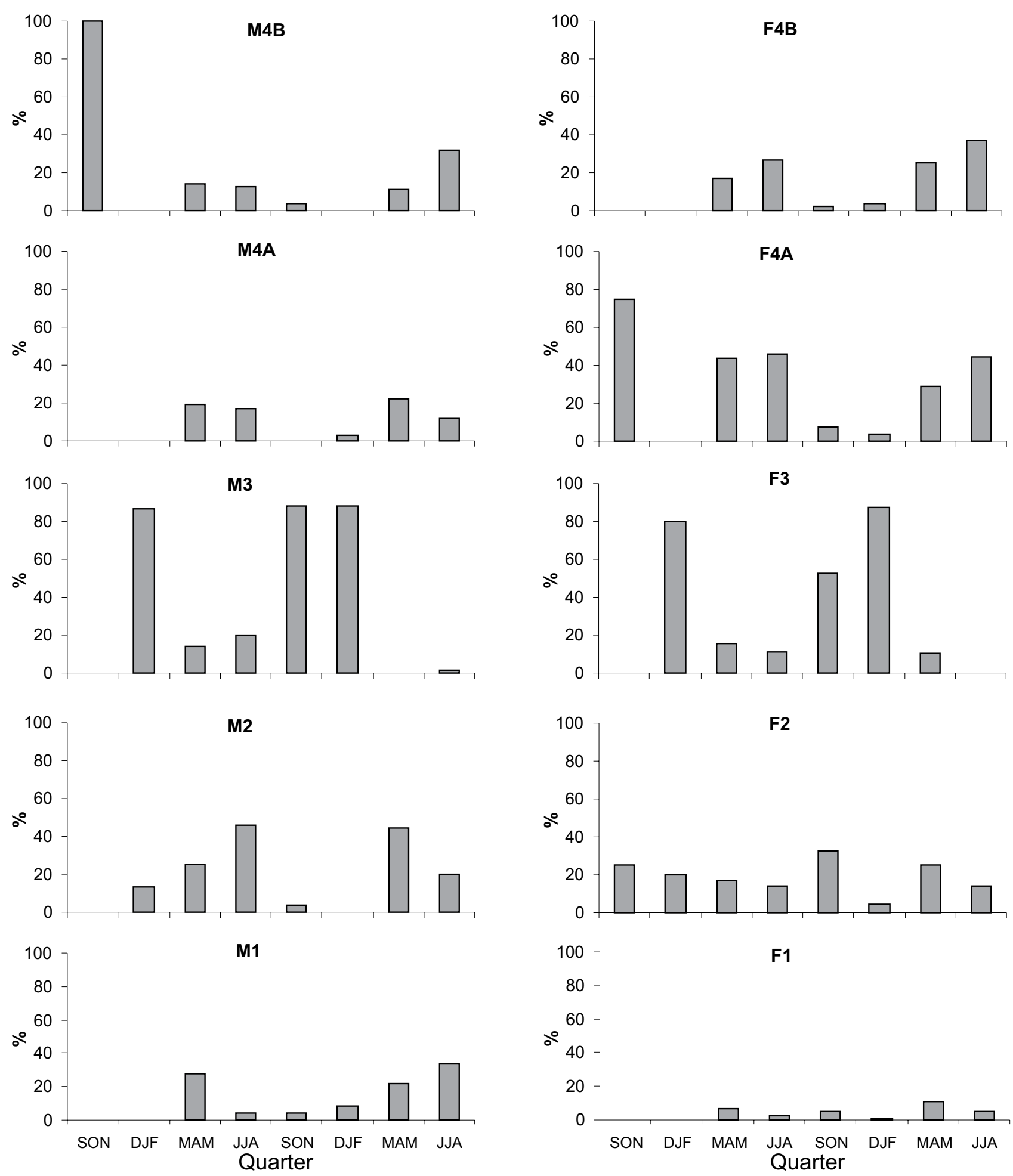

Figure 1. Quarterly distribution of percentual (\%) frequencies of the stages of the reproductive cycle of S. insculpta males (M) and females (F) captured in the Furnas reservoir, from September/1992 to August/1994 ( 1 =rest, 2 =initial ripening, 3 =advanced ripening/mature, 4A $=$ partially spent for males and partially spawned for females, and $4 \mathrm{~B}=$ totally spent for males and totally spawned for females). 
Table I. Macroscopic characteristics of testes and ovaries of S. insculpta collected in the Furnas reservoir from September/1992 to August/1994, in the various stages of the reproductive cycle (SRC).

\begin{tabular}{cll}
\hline SRC & \multicolumn{1}{c}{ Testes } & \multicolumn{1}{c}{ Ovaries } \\
\hline 1 & $\begin{array}{l}\text { Rose-colored, elongated, filiform, with a translucent aspect. } \\
\text { Whitish, voluminous, with blood vessels evident. }\end{array}$ & $\begin{array}{l}\text { Rose-colored, thin, translucent, with little vascularization. } \\
\text { Yellowish, voluminous, with rare oocytes visible to the } \\
\text { naked eye and blood vessels evident. } \\
\text { Yellowish, very voluminous, with a large number of }\end{array}$ \\
4A & $\begin{array}{l}\text { Milky-whitish, attaining maximum volume, with blood vessels } \\
\text { evident. }\end{array}$ & $\begin{array}{l}\text { Yeddish, flaccid, reduced volume, blood vessels less evident. } \\
\text { oocytes visible to the naked eye, blood vessels evident. } \\
\text { Light brown, flaccid, with hemorrhagic areas containing } \\
\text { oocytes visible to the naked eye, blood vessels less evident. } \\
\text { Brown-colored, with opaque oocytes visible to the naked } \\
\text { eye, blood vessels not very evident. }\end{array}$ \\
\hline
\end{tabular}

(1) Rest, (2) initial ripening, (3) mature, (4a) partially spent/spawned, (4b) totally spent/spawned.

Table II. Mean values of the gonadosomatic (GSI), hepatosomatic (HSI), stomach repletion (SRI), and coelomic fat (CFI) indexes and condition factors (K1 and $\mathrm{K} 2$ ), in each stage of the reproductive cycle (SRC) of S. insculpta males collected in the Furnas from September/1992 to August/1994.

\begin{tabular}{cccccccc}
\hline SRC & N & GSI & HSI & SRI & CFI & K1 & K2 \\
\hline 1 & 39 & $0.25 \pm 0.19 \mathrm{c}$ & $0.46 \pm 0.69 \mathrm{a}$ & $1.35 \pm 0.44 \mathrm{ab}$ & $0.96 \pm 1.21 \mathrm{a}$ & $2.60 \pm 0.43 \mathrm{a}$ & $2.59 \pm 0.43 \mathrm{a}$ \\
2 & 60 & $0.78 \pm 0.44 \mathrm{~b}$ & $0.40 \pm 0.29 \mathrm{a}$ & $1.29 \pm 0.43 \mathrm{bc}$ & $0.71 \pm 0.77 \mathrm{ab}$ & $2.48 \pm 0.34 \mathrm{a}$ & $2.46 \pm 0.34 \mathrm{ab}$ \\
3 & 86 & $2.49 \pm 1.02 \mathrm{a}$ & $0.38 \pm 0.24 \mathrm{a}$ & $1.14 \pm 0.38 \mathrm{c}$ & $0.73 \pm 0.66 \mathrm{ab}$ & $2.43 \pm 0.26 \mathrm{a}$ & $2.46 \pm 0.26 \mathrm{~b}$ \\
4A & 29 & $0.50 \pm 0.27 \mathrm{c}$ & $0.41 \pm 0.15 \mathrm{a}$ & $1.50 \pm 0.45 \mathrm{a}$ & $0.43 \pm 0.38 \mathrm{~b}$ & $2.48 \pm 0.35 \mathrm{a}$ & $2.55 \pm 0.35 \mathrm{ab}$ \\
4B & 36 & $0.40 \pm 0.31 \mathrm{c}$ & $0.41 \pm 0.17 \mathrm{a}$ & $1.37 \pm 0.19 \mathrm{ab}$ & $0.87 \pm 0.84 \mathrm{a}$ & $2.55 \pm 0.63 \mathrm{a}$ & $2.55 \pm 0.63 \mathrm{ab}$ \\
\hline
\end{tabular}

(N) Number of examples by SRC. In the same column, different superscript letters indicate statistically significant differences ( $p<0.05)$.

Table III. Mean values of the gonadosomatic (GSI). hepatosomatic (HSI). stomach repletion (SRI). and coelomic fat (CFI) indexes and condition factors (K1 and K2). in each stage of the reproductive cycle (SRC) of S. insculpta females collected in the Furnas reservoir from September/1992 to August /1994.

\begin{tabular}{cccccccc}
\hline SRC & N & GSI & HSI & SRI & CFI & K1 & K2 \\
\hline 1 & 17 & $0.67 \pm 0.62 \mathrm{c}$ & $0.49 \pm 0.25 \mathrm{ab}$ & $1.33 \pm 0.47 \mathrm{a}$ & $1.00 \pm 0.98 \mathrm{a}$ & $2.42 \pm 0.31 \mathrm{~b}$ & $2.39 \pm 0.32 \mathrm{ab}$ \\
2 & 74 & $3.99 \pm 2.75 \mathrm{~b}$ & $0.56 \pm 0.35 \mathrm{a}$ & $1.27 \pm 0.47 \mathrm{a}$ & $0.93 \pm 0.75 \mathrm{a}$ & $2.45 \pm 0.36 \mathrm{~b}$ & $2.35 \pm 0.34 \mathrm{ab}$ \\
3 & 181 & $13.25 \pm 5.05 \mathrm{a}$ & $0.38 \pm 0.24 \mathrm{~b}$ & $0.98 \pm 0.36 \mathrm{~b}$ & $0.77 \pm 0.60 \mathrm{a}$ & $2.69 \pm 0.35 \mathrm{a}$ & $2.33 \pm 0.32 \mathrm{~b}$ \\
$4 \mathrm{a}$ & 147 & $1.76 \pm 3.05 \mathrm{c}$ & $0.41 \pm 0.37 \mathrm{~b}$ & $1.24 \pm 0.35 \mathrm{a}$ & $0.82 \pm 1.50 \mathrm{a}$ & $2.47 \pm 0.31 \mathrm{~b}$ & $2.43 \pm 0.31 \mathrm{ab}$ \\
$4 \mathrm{~B}$ & 92 & $0.78 \pm 0.35 \mathrm{c}$ & $0.41 \pm 0.21 \mathrm{~b}$ & $1.38 \pm 0.33 \mathrm{a}$ & $0.68 \pm 0.93 \mathrm{a}$ & $2.50 \pm 0.33 \mathrm{~b}$ & $2.47 \pm 0.33 \mathrm{a}$ \\
\hline
\end{tabular}

(N) Number of examples by SRC. In the same column, different superscript letters indicate statistically significant differences ( $p<0.05)$.

(1999) who also correlated GSI increasing with the lowering of the mesenteric fat at higher rates in females than in males.

The GSI and HSI of S. insculpta showed an inverse relation over the reproductive cycle, similarly to what was reported by Yoneda et al. (1998), Hojo et al. (2004), Magalhães et al. (2004) and Alvarenga et al. (2006). The HSI of females reached higher values, when compared with those of males, and felt abruptly during the advanced ripening/mature stage, at which time the GSI became higher, indicating the consumption of hepatic reserves during ovarian maturation. This occurs as a result of depletion of the storage of glycogen and lipids of hepatocytes (SVEDÄNG \& WICKSTRÖM 1997), vitellogenin synthesis and transfer to the oocytes (LuzzAnA et al. 1996). The HSI may also vary between teleosts species, due to the differences in energetic reserve storage capacity, physiological condition, feeding habits, and availability of nutrients in the habitat (SVEDÄNG \& WICKSTRÖM 1997). Therefore, variations in the relation between GSI and HSI are attributable not only to gonadal maturation, but also to the physiological and adaptational capacity of each species, as well as to environmental conditions.

Both males and females showed lower SRI values in the advanced ripening/mature stage. The reduction in the feeding activity during the reproductive period is due to compression of the digestive organs by the gonads, particularly in females, with feeding being resumed immediately after spawning (SLOTTE 1999), as was observed in the present study. In the same way,

Revista Brasileira de Zoologia 24 (1): 71-76, março 2007 
in C. lepidura of the Juramento reservoir, Minas Gerais, Brazil, the stomach repletion was higher in the dry season, when fish are not in the reproduction season (Alvarenga et al. 2006).

The CFI values of males and females were lower in the partially spent and totally spawned stages, respectively, pointing to the consumption of lipids during spermiation and ovulation, even though no significant differences were recorded in the CFI of females. Differences in CFI values between males and females showed by teleosts during the reproductive cycle can be attributed to the conversion of fat reserves into products needed for gonadal maturation, since only in females the metabolism of lipids is naturally accelerated by large quantities of ovarian steroids (RAJASILTA et al. 1997).

In males of $\mathrm{S}$. insculpta, discreet variations of $\mathrm{K} 1$ and $\mathrm{K} 2$ were recorded over the reproductive cycle. In females, the highest $\mathrm{K} 1$ as well as the lowest $\mathrm{K} 2$ values were obtained during maturation confirming the influence of the weight of the ovaries upon the physiological condition of the females, as was observed in Steindachnerina elegans (Steindachner, 1874) by ALVES \& GodINHO (1992).

In conclusion, S. insculpta spawned almost throughout the year in the Furnas Reservoir. The species showed fractionated spawning with peaks of advanced maturation/maturefrom December to February. During the reproductive period the species eat less and consume more fat reserves. In females, the weight of the ovaries influenced the condition factor and hepatic substances were transferred from liver to ovaries during gonadal maturation.

\section{ACKNOWLEDGMENTS}

To Furnas Hydrobiology and Hatchery Station (Furnas Centrais Elétricas S/A) staff for the assistance during the collection of fish, to the Brazilian Research Foundations: CNPq, FAPEMIG and FIP-PUC-Minas for the financial support and Robert J. Young for the suggestions on the English version.

\section{REFERENCES}

Alvarenga, E.R.; N. Bazzoli; G.B. Santos \& E. Rizzo. 2004. Reproductive biology and feeding of Curimatella lepidura (Eigenmann \& Eigenmann) (Pisces, Curimatidae) in Juramento Reservoir, Minas Gerais, Brazil. Revista Brasileira de Zoologia 23 (2): 314-322.

Alves, C.B.M. \& H.P. Godinho. 1992. Ciclo reprodutivo e relação peso-comprimento de fêmeas de Steindachnerina el egans (Steindachner, 1874) (Ostariophysi, Curimatidae) na represa de Três Marias, MG, p. 20-27. In: H.P. Godınho \& P.M. BARBoSA (Eds). Aquicultura em Minas Gerais. Belo Horizonte, Associação Mineira de Aqüicultura, 122p.

BARBIERI, G. \& J.R. Verani. 1987. O fator de condição como indicador do período de desova em Hypostomus aff. plecostomus (Linnaeus, 1758) (Osteichthyes, Loricariidae), na represa do Monjolinho (São Carlos, SP). Ciência e Cultura 39: 655-658.
BAzzolı, N. 2003. Parâmetros reprodutivos de peixes de interesse comercial na região de Pirapora, p. 285-300. In: H.P.Godinho \& A.L. Godinho (Eds). Águas, peixes, e pesca no São Francisco da Minas Gerais. Belo Horizonte, Ed. PUC Minas, 438p.

Benedito-Cecílio, E. \& A.A. Agostinho. 1997. Estrutura das populações de peixes do reservatório de Segredo, p.113-139. In: A.A. Agostinho \& L.C. Gomes (Eds). Reservatório de Segredo: bases ecológicas para o manejo. Maringá, EDUEM, 387p.

Campos, E.C; J.J.C. Câmara; A.M. Rodrigues; R.A. Santos \& J.M. JUNIOR. 1991. Pesca sel etiva do sagüiru-prata, Steindachnerina insculpta (Fernandez-Yépez, 1948) (Characiformes, Curimatidae), com utilização de redes de emal har, na represa de Ibitinga, rio Tietê, estado de São Paulo, Brasil. Boletim do Instituto de Pesca 18: 23-30.

Godoy, M.P. 1975. Peixes do Brasil - subordem Characoidei. Piracicaba, Ed. Franciscana, vol. 3, 230p.

HARTZ, S.M. \& G. BARBIERI. 1994. Dinâmica da reprodução de Cyphocarax voga (Hensel, 1869) da lagoa do Emboaba, RS, Brasil (Characiformes, Curimatidae). Revista Brasileira de Biologia 54 (3): 459-468.

Hojo, R.E.S.; G.B. Santos \& N. Bazzolı. 2004. Reproductive biology of Moenkhausia intermeida (Eigenmann) (Pisces, Characiformes) in Itumbiara Reservoir, Goiás, Brazil. Revista Brasileira de Zoologia 21 (3): 519-524.

LAMAS, I.R. \& A.L. Godinho. 1996. Reproduction in the piranha Serrasalmus spilopleura, a neotropical fish with an unusual pattern of sexual maturity. Environmental Biology of Fishes 45: 161-168.

LOWE-M CCONNELL, R.H. 1987. Ecological studies in tropical fish communities. New York, Cambridge University Press, 382p.

Luzzana, U.; G. Serrini; V.M. Moretti; P. Grimaldi; M.A. Paleari \& F. VALFREÉ. 1996. Seasonal variations in fat content and fatty acid composition of male and female coregonid "Bondella" from Lake Maggiore and Iandlocked Shad from Lake Como (Northern Italy). Journal of Fish Biology 48: 352-366.

MADDOCK, D.M. \& M.P.M. BuRTON. 1999. Gross and histological observations of ovarian development and related condition changes in American Plaice. Journal of Fish Biology 53: 928-944.

Magalhães, A.L.B.; N. Bazzoli; G.B. Santos \& E. Rizzo. 2004. Reproduction of the South American Dogfish characid, Galeocharax knerii, in two reservoirs from upper Paraná river basin, Brazil. Environmental Biology of Fishes 70: 415-425.

Mcevor, L.A. \& J. Mcevor. 1992. Multiple spawning in several commercial fishes and its consequences for fisheries management, cultivation and experimentation. Journal of Fish Biology 41: 125-136.

NIKOLSKI, G.V. 1963. The ecology of fishes. London, Academic Press, 352p.

RajAsilta, M.; J. Paranko \& P.T. Laina. 1997. Reproductive characteristics of the male herring in the northern Baltic Sea. Journal of Fish Biology 51: 978-998.

Revista Brasileira de Zoologia 24 (1): 71-76, março 2007 
Reis, R.E.; S.O. Kullander \& C.J. Ferraris. 2003. Check list of the freshwater fishes of South and Central America. Porto Alegre, EDIPUCRS, 729p.

RinCHARD, J. \& P. KESTEMONT. 1996. Comparative study of reproductive biology in single-and-multiple-spawner cyprinid fish. I. Morphological and histological features. Journal of Fish Biology, London, 49: 883-984.

Romagosa, E.; H.M. Godinho \& M.Y Narahara. 1984. Tipo de desova e fecundidade de Curimatus gil berti (Quoy \& Gaimard, 1824) da represa do Ponte Nova, Alto Tietê. Revista Brasileira de Biologia 44 (1): 1-8.

SAM PAIO, I.B.M. Estatística aplicada à experimentação animal. Belo Horizonte, Fundação de Ensino e Pesquisa em Medicina Veterinária e Zootecnia, 221p.

SAntos, G.B. \& P.S. Formagio. 2000. Estrutura da ictiofauna dos reservatórios do rio Grande, com ênfase no estabelecimento de peixes piscívoros exóticos. Informe Agropecuário 21(203): 98-106.

Received in 29.III.2006; accepted in 26.II.2007.
SlotTE, A. 1999. Differential utilization of energy during wintering and spawning migration in Norwegian springspawning Herring. Journal of Fish Biology 54: 338-355.

SVEDÄNG, H. \& H. WICKSTRÖM. 1997. Low fat contents in female silver eels: indications of insufficient energetic stores for migration and gonadal development. Journal of Fish Biology 50: 475-486.

VAZzoler, A.E.A.M. 1996. Biologia da reprodução de peixes teleósteos: teoria e prática. Maringá, EDUEM, 169p.

Vazzoler, A.E.A.M. \& N.A. Menezes. 1992. Síntese de conhecimentos sobre o comportamento reprodutivo dos Characiformes da América do Sul (Teleostei: Ostariophysi). Revista Brasileira de Biologia 52 (4): 627:640.

Yoneda, M.; M. Tokimura; H. Fujita; N. Takeshita; K. Takeshita; Matsuyama M. \& S. Matsuura. 1998. Reproductive cycle and sexual maturity of the anglerfish Lophiomus setigerus in the East China Sea with a note on specialized spermatogenesis. Journal of Fish Biology 53: 164-178. 